\title{
Environmental impact of methane released from coal mines
}

\author{
Nicolae Ianc ${ }^{1}$, Corneliu Boantă ${ }^{1}$, Ion Gherghe $^{1}$, Cristian Tomescu ${ }^{1}$ \\ ${ }^{1}$ National Institute for Research and Development in Mine Safety and Protection to \\ Explosion - INSEMEX, 32-34 G-ral Vasile Milea Street, Petrosani, Hunedoara, Romania
}

\begin{abstract}
Methane gas accompanying coal deposits was formed as a result of successive stages of the anaerobic process of vegetal material transformation into coal, at high temperatures and pressures, without external oxygen supply. During the metamorphism process, the content of $\mathrm{C}, \mathrm{H}$ and $\mathrm{O}$ is modified, meaning an increase in carbon content, a decrease in hydrogen and oxygen, the nitrogen and sulphur content remaining constant. During this process, water and carbon dioxide is generated, the water being generated in the first transformation phases. Within the slow oxidation process, gas products result by using the oxygen content in plants, especially methane and carbon dioxide due to the fermentation stimulated by bacteria. Methane released into the atmosphere following the mining of coal have double ecological impact, participating in the destruction of the ozone layer and at the same time contributing to the enhancement of the greenhouse effect. At the same time, methane gas released into the atmosphere during coal mining may be used by mining operators as primary power resource for covering the power requirements of the mine or it can be used for commercial purposes.
\end{abstract}

\section{Introduction}

The methane gas that accompanies the coal deposits was formed as a product in the successive stages of the process of anaerobic conversion of the vegetal material into coal at high temperatures and pressures, during the carbonization process, without oxygen supply from the outside.

During the metamorphism process the content of $\mathrm{C}, \mathrm{H}, \mathrm{O}$ changes, which means an increase in $\mathrm{C}$ - carbon content, the content of $\mathrm{H}$ - hydrogen and $\mathrm{O}$ - oxygen decreases, while the content of $\mathrm{N}$ - nitrogen and S - sulfur remains constant. During the metamorphism process, water and carbon dioxide are formed, the water forming in the first phases of transformation of the carboniferous substance. [2]

In the process of slow oxidation, using oxygen contained in plants results in gaseous products, especially methane gas and carbon dioxide due to the methane fermentation stimulated by microorganisms such as bacteria and bacteria (micrococcus carbo).

*Corresponding author: nicolae.ianc@insemex.ro 
According to K. Patteisky's research, up to $350 \mathrm{~m} 3$ of methane gas and up to $200 \mathrm{~m} 3$ of carbon dioxide can be formed when forming a cubic meter of coal.

The complexity of the formation of many sources and chemical transformations of methane makes it difficult to understand and evaluate the contribution of this gas to global warming. However, its contribution to global warming is significant, due to the high value of global warming potential.

Methane, this entity present in the extraction of coal, has been over time the main danger and the object of major concerns in the research and acquisition of superior security conditions; it also constituted a continuous analysis point of maximum attention for three main reasons, namely: [7]

- methane is a natural product and occurs frequently in underground excavations;

- methane is the cause of several accidents with catastrophic consequences, which have resulted in losses of human lives, more than other risk factors in the history of mining;

- the need for rational use of methane capture-drainage technology.

Emissions of methane released into the atmosphere following coal mining have a dual ecological impact, namely, they participate in the destruction of the ozone layer and at the same time contribute to the greenhouse effect, but at the same time the methane gas released into the atmosphere concomitantly with the coal exploitation, may it can be used by mining operators as a primary energy resource to cover their own energy needs, or it can be used for commercial purposes.

The purpose of the studies and research undertaken was to establish the measures to reduce the impact of methane from the coal mines in the Jiu Valley, in the context of the current legislation on ensuring the safety and health of workers and reducing the effects of greenhouse gases on the environment.

Simultaneously with the increase of the concrete component of the carried-out researches, a significant role is played by two determinant vectors, namely the reduction of the risks for the safety and health of the workers and of the impact on the atmospheric environment of methane gas.

Two main directions are considered regarding the nature and magnitude of the environmental impact of methane gas released in the coal mines of the Jiu Valley, namely the impact of methane on the underground environment, on the safety and health of workers, on the one hand, and impact of methane from coal mines on global warming of the atmosphere. [3], [9]

So far, the capture and drainage of methane gas in the mines in the Jiu Valley has been made for reasons strictly related to the security of underground coal mining, the energy applications aiming only at partially covering the thermal energy requirement of the mining operators.

There has been a quasi-exhaustive analysis of the technical feasibility of modern technologies for the recovery of methane from coal mines worldwide. On this basis there are highlighted possibilities of reducing the impact on the environment by exploiting methane gas at the mines in the Jiu Valley.

The current possibilities of reducing methane emissions into the atmosphere, through its use, are considerably limited by a series of constraints caused by technological, commercial, political and institutional restrictions.

The extractive industry is characterized by specific working conditions, imposed by both the natural particularities and the character of the production process. These require a series of specific, complex measures, which are meant to create normal working opportunities, without jeopardizing the safety of workers, either through accidents or through occupational diseases.

On the other hand, according to the Intergovernmental Panel on Climate Change (IPCC), $17 \%$ of the overall effect of global warming is due to methane. Methane comes 
from a large number of sources, both anthropic and natural. Both types of sources contribute to the increase of the atmospheric concentration of methane, the major contribution being allocated to natural sources. Methane is rapidly transformed into less dangerous molecules that enter other transformation cycles.

Currently, the exploitation methods applied to the mines in the Jiu Valley have as common element the descending extraction in slices of the thick layers of coal, in this case layer 3, with the management of the mining pressure by the total suction of the rocks. In the case of the undermined coal bed exploitation method, the fragmentation and sifting of the rock mass is done on much larger areas, generating the occurrence of the exploitation holes and the remaining unused state of the coal in the exploited space.

In this case, through the current ventilation systems, the possibility of large accumulations of methane increases, which together with coal dust is the main source of formation of potentially explosive atmospheres, with all the adverse consequences on the safety of underground work and of an underground atmospheric environment corresponding to the normal conduct of extraction activities.

\section{Analysing the statistics of the collective accidents at the mines in the Jiu Valley}

A statistic of the collective accidents that have occurred in the last 35 years at the Valea Jiu mines unit, presented in the table, is particularly eloquent for the risk associated with the formation of explosive mixtures, given that the means of preventing the accumulation of methane have not expected effectiveness. The insufficient methane dispersion in the air currents, associated with technical failures and/or human errors, has generated numerous events with particularly serious human and economic consequences.

The global analysis of the available statistical data allowed the following aspects to be highlighted: out of a total of 34 events, classified as collective accidents, 13 represent explosions of methane, 12 ignitions of methane, 3 breaths, 2 poisonings with carbon monoxide, one explosion of hydrogen following thermal dissociation of water into hydrogen and oxygen, an explosion of coal dust, so out of the total 34 collective accidents investigated, 26 are generated by the accumulation of methane, i.e. $76.5 \%$ of the total number. [4]

$>\quad$ out of the total 344 victims of these dynamic phenomena, 239 lost their lives $(69 \%)$ and the other 105 registered temporary incapacity for work (31\%);

$>$ the 13 methane explosions resulted in 200 deaths $(83 \%$ of the total number of deaths) and 87 cases of temporary incapacity for work;

the 12 methane ignitions resulted in 5 deaths ( $2 \%$ of the total number of deaths) and 18 cases of temporary incapacity for work;

$>\quad$ the event framed by the investigations, as a "coal dust explosion" had as human effects 17 deaths ( $7 \%$ of the total number of deaths) and 7 persons who suffered variable periods of days of temporary incapacity to work. 
Table 1. Statistical data on collective work accidents produced between 1972 and 2007 at the mines in the Jiu Valley

\begin{tabular}{|c|c|c|c|}
\hline $\begin{array}{l}\text { Date of } \\
\text { place }\end{array}$ & Place & $\begin{array}{c}\text { The events effect and } \\
\text { characterization }\end{array}$ & Causes \\
\hline 2.11 .1972 & $\begin{array}{l}\text { EM Uricani, } \\
\text { Stope room, } \\
\text { layer. 3, bl. III }\end{array}$ & $\begin{array}{l}\text { Methane explosion } \\
\text { - } 53 \text { injured ( } 43 \text { deadly, } \\
10 \text { ITM) } \\
\text { - the interruption for } 2 \\
\text { hours of the ventilation in } \\
\text { zone bl.3 }\end{array}$ & $\begin{array}{l}\text { - Adopting an improper method of operating. } \\
\text { - Deficiencies in ventilation. } \\
\text { - Other organizational causes } \\
\text { - Switch AG } 25 \text {. }\end{array}$ \\
\hline 16.01 .1980 & $\begin{array}{l}\text { EM Petrila } \\
\text { Frontal stope } \\
\text { Str .13, str. 13, } \\
\text { panel B3, bl. I }\end{array}$ & $\begin{array}{l}\text { Ignition of methane } \\
-7 \text { injured ITM }\end{array}$ & $\begin{array}{l}\text { - Failure to work technology. } \\
\text { - Deficiencies in ventilation. } \\
\text { - Other organizational causes. }\end{array}$ \\
\hline 29.11 .1980 & $\begin{array}{l}\text { EM Livezeni, } \\
\text { Frontal stope } \\
\text { str.5, bl. VI }\end{array}$ & $\begin{array}{l}\text { Methane explosion } \\
-77 \text { injured (53 dead, } 24 \\
\text { ITM) }\end{array}$ & $\begin{array}{l}\text { - Deficiencies in ventilation. } \\
\text { - Improper maintenance and operation of } \\
\text { electromechanical installations. } \\
\text { - Other organizational causes. }\end{array}$ \\
\hline 18.02 .1982 & $\begin{array}{l}\text { EM Petrila } \\
\text { Stope room } \\
\text { no. } 331, \text { str.3, } \\
\text { bl. II }\end{array}$ & $\begin{array}{l}\text { Coal dust explosion } \\
-29 \text { injured (14 dead, } 15 \\
\text { ITM) }\end{array}$ & $\begin{array}{l}\text { - Adopting an inadequate working } \\
\text { technology. } \\
\text { - Other organizational causes. }\end{array}$ \\
\hline 9.09 .1982 & $\begin{array}{l}\text { EM Paroşeni } \\
\text { Shaft head } \\
\text { oriz.360, frontal } \\
\text { stope panel1, } \\
\text { str. 5, bl. V } \\
\end{array}$ & $\begin{array}{l}\text { Methane explosion } \\
-24 \text { injured (17 dead, } 7 \\
\text { ITM) } \\
\end{array}$ & $\begin{array}{l}\text { - Error in the realization of the system of } \\
\text { automatic decoupling of the electrical energy } \\
\text { - Other organizational causes }\end{array}$ \\
\hline 26.06 .1985 & $\begin{array}{l}\text { EM Aninoasa } \\
\text { Frontal stope } \\
\text { nr. 4, str. 3, bl. } \\
\text { V, } \\
\text { oriz. X }\end{array}$ & $\begin{array}{l}\text { Hydrogen explosion } \\
-4 \text { deadly injured }\end{array}$ & $\begin{array}{l}\text { - Implementation of an inappropriate } \\
\text { technology for extinguishing an endogenous } \\
\text { fire, which resulted in the thermal } \\
\text { dissociation of water, resulting in hydrogen } \\
\text { and oxygen } \\
\text { - Deficiencies in ventilation } \\
\text { - Other organizational causes } \\
\end{array}$ \\
\hline 21.03 .1986 & $\begin{array}{l}\text { EM Vulcan } \\
\text { Str.7, bl. 0, } \\
\text { oriz.420 }\end{array}$ & $\begin{array}{l}\text { Methane explosion } \\
-19 \text { injured (17 dead, } \\
2 \text { ITM) }\end{array}$ & $\begin{array}{l}\text { - Applying an inappropriate technology } \\
\text { during the shooting operation. } \\
\text { - Non-observance of the reinforcement } \\
\text { monograph, respectively the closure of the } \\
\text { old mining works and the exploited space. } \\
\text { - Failures in the ventilation. } \\
\text { - The wrong location of the methane } \\
\text { detection heads. }\end{array}$ \\
\hline 22.03 .1986 & $\begin{array}{l}\text { EM Vulcan } \\
\text { Str.7, b. } 0 \\
\text { oriz. } 420\end{array}$ & $\begin{array}{l}\text { Methane explosion } \\
-17 \text { injured ( } 8 \text { dead, } \\
9 \text { ITM) }\end{array}$ & $\begin{array}{l}\text { - Other organizational causes, namely } \\
\text { granting the acceptance to enter an area with } \\
\text { an explosive concentration of methane }\end{array}$ \\
\hline 18.09 .1989 & $\begin{array}{l}\text { EM Vulcan } \\
\text { panel 1, } \\
\text { str.5, bl. 0 }\end{array}$ & $\begin{array}{l}\text { Methane explosion } \\
-39 \text { injured ( } 29 \text { dead, } 10 \\
\text { ITM) }\end{array}$ & $\begin{array}{l}\text { - Failure to carry out measures to combat the } \\
\text { accumulation of methane and coal dust } \\
\text { - Use of open flame devices underground, } \\
\text { without taking appropriate measures } \\
\text { - Failures in the ventilation. } \\
\text { - Incorrect location of methane detection } \\
\text { heads }\end{array}$ \\
\hline $\begin{array}{l}13-14.11 \\
1991\end{array}$ & $\begin{array}{l}\text { E.M. Uricani } \\
\text { Frontal stope, } \\
\text { panel } 1, \text { str. } 3\end{array}$ & Ignition of methane & $\begin{array}{l}\text { - Accumulation of methane } \\
\text { - Development of a spontaneous combustion } \\
\text { phenomenon }\end{array}$ \\
\hline
\end{tabular}




\begin{tabular}{|c|c|c|c|}
\hline $\begin{array}{l}\text { Date of } \\
\text { place }\end{array}$ & Place & $\begin{array}{l}\text { The events effect and } \\
\text { characterization }\end{array}$ & Causes \\
\hline 17.06 .1993 & $\begin{array}{l}\text { E.M. Paroşeni } \\
\text { Frontal stope } \\
\text { str. 5, bl. V }\end{array}$ & Ignition of methane & $\begin{array}{l}\text { - Accumulation of methane } \\
\text { - Shooting operation }\end{array}$ \\
\hline 21.06 .1993 & $\begin{array}{l}\text { E.M. Vulcan } \\
\text { Mine workings } \\
\text { de la str. 3, bl. } \\
\text { II }\end{array}$ & $\begin{array}{l}\text { Flowing with carbon } \\
\text { oxyde }\end{array}$ & - Inadequate dam sealing methods \\
\hline 12.08 .1994 & $\begin{array}{l}\text { E.M. Câmpu } \\
\text { lui Neag } \\
\text { Room stope, } \\
\text { str.17/18. bl. } \\
\text { VI. S }\end{array}$ & Ignition of methane & $\begin{array}{l}\text { - Accumulation of methane } \\
\text { - Electrical short circuit }\end{array}$ \\
\hline
\end{tabular}

In conclusion, it is estimated that $92 \%$ of the deaths resulting from the collective accidents investigated were due to events having as one of the primary causes the existence of underground methane accumulations, which gives us the right to assert that the assiduous research aimed at knowing the related elements by the occurrence and prevention of the danger caused by methane gas, it shows that no price is too high to reward research in the field of control and control of underground work security. [6], [10]

\section{The impact of methane on global warming of the atmosphere. Greenhouse effect. Mechanism and factors of influence}

The greenhouse effect is an essential natural feature of the terrestrial system, which has exerted its action since the earliest geological eras in Earth's history and is due to the presence in the atmosphere of gases such as: $\mathrm{CO} 2$ carbon dioxide, $\mathrm{N} 2 \mathrm{O}$ nitrogen oxide, $\mathrm{CH} 4$ methane, $\mathrm{O} 3$ ozone and water vapor.

The greenhouse effect as a whole determines the maintenance of a relatively constant temperature on the earth's surface, favourable to the development of life, being the most important factor of radiative forcing. This effect consists in the partial retention in the atmosphere of the solar radiation of short waves, reflected by the terrestrial surface in the form of caloric radiation with long waves.

The greenhouse gases mentioned absorb these radiations and relay them to the earth's surface. In this way, both the atmosphere and the land surface are warmer than if there was no such concentration of greenhouse gases. In the event that there were no greenhouse gases (especially water vapor and carbon dioxide), the terrestrial atmosphere would be $33^{\circ}$ C cooler.

Water vapor from the atmosphere, natural gas and particles such as carbon dioxide, nitric acid, methane gas and ozone allow the short-wave radiation, full of energy from the Sun to Earth to pass, but absorbing the long radiation emitted by the Earth. Greenhouse gases emit this energy, on the one hand, in space, and on the other, back to Earth.

Although the rise in temperature has been observed for over 100 years, over the past 30 years the global average temperature rise has been on a steep upward curve. Since 1976, the global average temperature has increased by $0.180 \mathrm{C}$ per decade. In both hemispheres of the Earth, the decade of the 90's was the hottest. Carbon dioxide is the most important greenhouse gas (accounting for about $50 \%$ of the anthropogenic greenhouse effect). According to the IPCC report of 2001, starting with 1750 there was a $31 \%$ increase in CO2 concentration in the atmosphere. About $75 \%$ of anthropogenic $\mathrm{CO} 2$ emissions in the atmosphere over the last 20 years are caused by the burning of fossil fuels. [1] The concentration of methane gas in the atmosphere increased from 1750 by $151 \%$, still 
increasing. Methane gas molecules have a high heat absorption capacity, which means that lower concentrations also make an important contribution to the greenhouse effect. Methane gas is formed by bacterial decomposition of organic material under anaerobic conditions.

Partially fluorinated and chlorinated hydrocarbons, as well as fully halogenated (FCKW) hydrocarbons are purely synthetic (not in nature), their sources being: aerosols, foam as well as insulating substances, refrigerants from refrigerators and refrigeration plants, solvents and products for cleaning. They are not only gases that produce the greenhouse effect, being mainly responsible for the decomposition of the ozone layer. As a result of the measures adopted by the Montreal Protocol, FCKW concentrations have not increased, fortunately, since 1996, even down the slope. SF6 sulphur hexafluoride is the gas with the highest potential for greenhouse effect. One tonne of SF6 pollutes the atmosphere to an extent that corresponds to about 23,900 tons of $\mathrm{CO} 2$. A new, much more in-depth analysis provides interesting and relevant information for the current climate warming period. [8]

If until about one hundred years ago the changes were due exclusively to natural causes, at present the anthropic factor is very important in this process. No one can say very clearly what is the part that is due to man and what nature is at the moment. There are many opinions and polemics, but one thing is very clear: at present, the terrestrial climate is warming at an alert pace, with consequences that are difficult to quantify in the medium or long term. Only in the last 2 decades has the change become evident, both in terms of the thermal regime, but especially in terms of fluctuations generating extreme weather phenomena, typical of a rapidly changing climate.

Of all the factors that influence the climate, it seems that the one that has to be taken into account in the highest degree is that of the emission of carbon dioxide into the atmosphere, due to the greenhouse effect produced. The conclusion that can be drawn very easily is that the current heating is not caused by an increase in solar activity, but is in close correlation with the emission of carbon dioxide.

Global warming has become, from time to time, the "possible" explanation for all extreme natural phenomena: moving the tropics, expanding deserts, cold waves and, more recently, hurricane intensity. Scientists also predict a number of future effects of global warming.

A warmer planet will have more rainfall, but people will not have the capacity to manage large amounts of water. Moreover, at the rate of melting glaciers, they will disappear completely in just a few decades.

Until recently, scientists have embraced the idea that the global warming phenomenon will cause major changes and acute problems in the world, but in their thinking, the scenario predicted that they would occur in a period of 50 to 100 years and that only then will the effects be felt.

The general idea was that global warming is a slow process and that humanity will have time to discover ingenious solutions to all problems. New, well-documented evidence suggests that this scenario is completely wrong and that we should be prepared for particularly abrupt climate change. It was explained how the melting of the northern and southern polar caps, which are composed of fresh water, is the deciding factor in a global meteorological disaster.

There are other possible sources for the release of methane into the atmosphere. For example, warming the planet can intensify the release of this gas from the sediments of the oceans, swamps, peatlands and permafrost (permanently frozen soil layer from high altitudes). In these areas, a significant amount of methane remains "trapped" between water molecules and a rise in temperature can cause the release of this gas. The average lifetime 
of methane in the atmosphere is relatively short (12 years) compared to that of carbon dioxide (50-200 years) and other greenhouse gases.

After the years 1990 - 1995, the greenhouse gas emissions decreased mainly due to the reduction of the economic activity, but also by starting some programs to reduce the emissions. Among the pollutants regulated by the Kyoto Protocol, in Romania are greenhouse gas emissions: carbon dioxide, nitrogen oxides and methane.

\section{Conclusions}

Over time, methane has been the main danger and the subject of major concerns in the research and acquisition of superior security conditions, it has also been a continuous point of maximum attention for three main reasons:

- methane is a natural product and occurs frequently in underground excavations;

- methane is the cause of several accidents with catastrophic consequences, which have resulted in losses of human lives, more than other risk factors in the history of mining;

- the need for rational use of the methane capture and drainage technology;

If up to a hundred years ago the changes were due exclusively to natural causes, at present the anthropic factor is of great importance in this process;

The greenhouse effect as a whole determines the maintenance of a relatively constant temperature on the Earth's surface, favourable to the development of life, being the most important factor of radiative forcing.

\section{References}

1. Acot, P. - Histoire du climat, du Big Bang au catastrophes climatiques, Edition Perrin, Paris 2004

2. Ciulache, S., Ionac, N. - Atmospheric phenomena of risk (in Romanian), Editura Stiintifica, Bucuresti, 1995

3. Cozma, E., Goldan, T. - Design of mines (in Romanian), Editura Focus, Petrosani, 2003

4. Goldan, T. - Optimization of the parameters of the methods of exploitation of the thick layers with high inclination, in order to reduce the danger of coal self-ignition (in Romanian), Teza de doctorat, Universitatea din Petrosani, 1999

5. Ianc, N. - Contributions on preventing and combating the effects of explosions on gas accumulations on the environment, Doctoral Report no. 3 (in Romanian), Universitatea din Petroaani, octombrie, 2007

6. Ianc, N., s..a.- Evaluation and reduction of risk factors in the mine closure activity (in Romanian), Study S.C. INSEMEX S.A, 1999

7. Matei, I., Moraru, R., Samoilă, M., Băbuţ, G. - Environmental engineering and underground ventilation (in Romanian), Ed. Tehnica, Bucuresti, 2000

8. Moraru, R. - Climatology (in Romanian), Ed. Universitas, Petrosani, 2009

9. Onica, I., Chiril, M. - Undermining of coal mines (in Romanian), Editura AGIR, Bucuresti, 2005

10. XXX - Technical expertise reports on the causes of events, accidents, damage during the period 1991-2008 (in Romanian), S.C. INSEMEX S.A. Petrosani

11. XXX - http://www.coogee.com.au/methanol/process.htm; $6^{\text {th }}$ January 2004 